\title{
MILK PRODUCTION AND FEED UTILIZATION OF ZARAIBI GOATS FED SOME FORAGE PROTEIN SOURCES SUCH AS BERSEEM OR KOCHIA SILAGE AND THEIR MIXTURE WITH FODDER BEET. \\ Maged, G. A.; W.M.A. Sadik; G.I. El-Emam; M.E. El-Kholany and T.H. El-Sawah. \\ Animal Production Research Institute, Agricultural Research Center, Dokki, Giza, Egypt.
}

\begin{abstract}
Eighteen dairy Zaraibi goats in $2^{\text {nd }}, 3^{\text {rd }}$ and $4^{\text {th }}$ season of lactation with average body weight of $37.87 \mathrm{~kg}$ were divided randomly into three equal groups, to study the effect of substitution of berseem silage by Kochia as a source of protein in silage rations on milk yield, blood profile and feed efficiency of dairy goats. Half the crude protein $(\mathrm{CP})$ requirements of lactating goats were covered from CFM. The other $50 \%$ of $\mathrm{CP}$ was covered from: berseem silage in the first group $\left(\mathrm{G}_{1}\right), 50 \%$ berseem $+50 \%$ fodder beet silage in second group $\left(\mathrm{G}_{2}\right), 50 \%$ Kochia $+50 \%$ fodder beet silage in third group $\left(\mathrm{G}_{3}\right)$. The feeding trails lasted for 14 weeks. The obtained results showed that the crude protein (CP) and crude fiber (CF) percentages of berseem silage were higher 14.20 and $29.80 \%$ than the other silages. But, the content of EE and NFE were lower $(2.05$ and $41.95 \%)$ in berseem silage compared with two mixture silages. But, organic matter (OM) was nearly similar in the different silages. The effect of the tested silages on most hemato-biochemical parameters was not significant. Concerning milk production, the obtained data indicated that the highest value of milk yield was recorded with $G_{1}(845 \mathrm{~g} / \mathrm{h})$ followed by $G_{2}(761 \mathrm{~g} / \mathrm{h})$, while the lowest value $(727 \mathrm{~g} / \mathrm{h})$ was recorded with $\mathrm{G}_{3}$ and the differences were significant. Moreover, milk fat percentage was significantly $(P<0.05)$ higher with $G_{3}$ (Kochia-fodder beet silage) compared with the other groups. The same trend was observed also with total solids among the three groups. The effect of experiment rations on other milk content (milk protein, lactose and ash) and milk quality parameters was not significant. The feed conversion efficiency based on $D M$ and $C P$, was better with $G_{1}$ compared $G_{3}$. On the contrary, the economic efficiency was better with $\mathrm{G}_{3}$ compared with the other groups.

Keywords: Mixture silage, Kochia, Fodder beet, Economic efficiency, Lactating goats.
\end{abstract}

\section{INTRODUCTION}

Fodder beet is an excellent forage for dairy animals in winter time when green fodder are not available (Donosa, 2010). Fodder beet is an important forage in dairy cows feeding due to its high productivity and quality (lacob, 1997). Fodder beet is a succulent winter forage characterized by high moisture (70-90\%) and energy content. In this respect, Marius et al.(2004) stated that the concentration of saturated FA's was very high in milk fat of cows fed fodder beet rations.

In a recent study, Hanafy et al. (2013) studied the effect of using Kochia indica plant in different forms (fresh, hay or silage) in Barki sheep rations on palatability, digestion coefficients and nutritive value. Concentrate feed mixture was offered to cover $60 \%$ of maintenance requirements of sheep, while Kochia plants were offered ad lib. for the three animal groups. 
Dry matter intake values from Kochia in different forms with CFM showed that ensiling process significantly improved its palatability by $61 \%$ compared to hay form. Crude fiber digestibility of Kochia silage was higher $10 \%$ and $31 \%$ than that of fresh and hay. respectively. Besides, nutritive value as TDN and DCP\% were significantly differed and recorded the highest value for Kochia silage (62.5 and $9.5 \%$ ), while the lowest value was recorded for Kochia hay (52.8 and 6.9\%). In addiction several studies (Sherrod, 1973, Zahran, 1986, Tag El-Din et al. 1991, Shehata et al. 2001 and Hanafy et al. 2011) indicated that Kochia plant could be used as a good quality forage for ruminants in summer for its high content of crude protein and feeding values especially when harvested in earlier growth stages.

On the other hand, other studies were carried out to utilize some legumes and grass mixtures in farm animals feeding such as berseem with sorghum (El-Kolany, 1998), Kochia indica with teosinte (Ahmed et al., 2001) Sesbania sesban with Millet $x$ Napier grass hybrid (Ibrahim et al., 2012) and triticale with berseem (Ahmed et al., 2013 and El-Emam et al., 2014). Therefore, the main objective of the present study was to investigate the effect of feeding some forage protein sources (berseem or Kochia) and their mixtures with fodder beet in silage rations on milk production and feed conversion efficiency of lactating Zaraibi goats. Blood parameters were also studied.

\section{MATERIALS AND METHODS}

This study was conducted at the Animal Production Research Station, El-Serw, belonging to Animal Production Research Institute, Agricultural Research Center, Egypt.

Eighteen Zaraibi goats, selected from El-Serw Station Herd, with an average age of 3 to 6 years and $37.87 \mathrm{~kg}$ body weight were used. The animals were divided randomly according to body weight and previous milk production into three similar group, 6 does each. The animals were weighed at the beginning then biweekly. Animals were fed for 2 weeks as a transitional period on the tested experimental rations before the start of the experimental work. Feeding the experimental rations lasted for 14 weeks.

All groups were fed on restricted amount of concentrate feed mixture (CFM), to cover $50 \%$ of the requirements according by NRC (1981) for lactating goats. Yet, a combination of different silages were fed ad lib. The animals were fed as follows: ration1: CFM+berseem (trifolium alexandarinum) $\left(2^{\text {nd }}\right.$ cut) silage $(\mathrm{G} 1)$, ration2: $\mathrm{CFM}+(50 \%$ berseem $+50 \%$ fodder beet) silage (G2) and ration3: CFM+(50\% Kochia $+50 \%$ fodder beet) silage (G3). The animals were fed in groups. The berseem and fodder beet were cultivated in El-Serw Experimental Station, while Kochia indica were harvested along the sub-roads from Damietta governorate during May and June at mid-bloom stage to prepared Kochia silage as reported by Shehata et al. (2001). Berseem silage was only prepared by adding $3 \%$ molasses on fresh bases as reported by Ahmed et al. (2013). The CFM consisted of 25\% undecortecated cotton meal, $43 \%$ yellow corn, $25 \%$ wheat bran, $3.5 \%$ molasses, $2 \%$ limestone, $1 \%$ common salt and $0.5 \%$ minerals mixtures. The rations were 
offered in two equal meals at 8 a.m. and at 3.0 p.m.. Water was available at all times. The chemical composition of the tested ingredients consumed by Zaraibi does is shown in Table (1). Samples of feed were analyzed according to the procedures of A.O.A.C. (1995). Blood samples were collected from the jugular vein once before feeding ( 3 animals in each) at the end of experimental period.

Blood samples were centrifuged at $4000 \mathrm{rpm}$ for $20 \mathrm{~min}$. Part of the separated serum was directed to enzyme activity determination, while the other part was stored frozen at $-20^{\circ} \mathrm{C}$ till the biochemical analysis. Commercial kits were used for colorimetric biochemical determination.

Milk yield was recorded daily for each doe. Representative milk samples (about $0.5 \%$ of total milk produced) were taken biweekly for each doe at both milking. Composite milk samples was analyzed for contents of total solids (T.S.) and protein according to methods described by Ling (1963). Fat content was determined by using Lactoscan made in Bulgaria. Lactose content was determined according to Barnett and Abd El-Tawab (1957). Ash content was determined as reported in A.O.A.C (1984). Milk pH values was measured digital pH meter WTW (720/7200) made in Germany sentix 61 Glass electrode.

Rheological properties of curd: Rennet coagulation time (RCT) was measured by Davies and White (1958). Crud tension was estimated as described according to Chandrosekhara et al. (1975). The rate of whey synesesis of fresh curd was measured as the volume of drained whey after $10,30,60,90,120 \mathrm{~min}$., it was calculated as a percent of the volume of milk according to Laurernce (1959).

Data were statistically analyzed using One-Way Layout with Means Comparisons Procedure SAS (2003).

\section{RESULTS AND DISCUSSION}

\section{Chemical composition:}

The chemical composition of different silages are presented in Table 1. It could be observed that CP content were noticeably higher with berseem silage $(14.20 \%)$ than those of berseem-fodder beet silage $(12.15 \%)$ or Kochia-fodder beet silage (12.39\%). While the content of EE and NFE were lower $(2.05$ and $41.95 \%)$ in berseem silage compared with the other silages rations (mixture silages).

Moreover, the highest value (29.80) of CF was recorded with berseem silage and the lowest value (18.35) was detected with Kochia-fodder beet silage. The differences in DM and OM were of fewer values. Similar results were reported by Al-Emam et al. (2014) who found that berseem silage contained $13.95 \% \mathrm{CP}, 28.90 \% \mathrm{CF}, 2.15 \mathrm{EE}, 43.0 \% \mathrm{NFE}$ and 12.0 ash, but DM was higher than that obtained herein (30.85 vs 28.50). The chemical composition obtained in present study was nearly similar to that obtained by Haggag et al. (2002) and Ahmed et al. (2013) for berseem and/or triticale and Ahmed et al. (2001) and Shehata et al. (2001) for Kochia and/or teosinte silage. 
Table (1): Chemical analysis of feed ingredients.

\begin{tabular}{|l|c|c|c|c|c|c|c|}
\hline \multirow{2}{*}{ Ingredients } & \multirow{2}{*}{ DM } & \multicolumn{7}{|c|}{ Chemical composition } \\
\cline { 3 - 8 } & & OM & CF & CP & EE & NFE & Ash \\
\hline $\begin{array}{l}\text { Concentrate feed mixture, } \\
\text { CFM }\end{array}$ & 91.50 & 94.00 & 15.90 & 14.50 & 3.20 & 60.40 & 6.00 \\
\hline $\begin{array}{l}\text { Berseem silage } \\
\begin{array}{l}\text { (50\% Berseem-50\% Fodder } \\
\text { beet) silage }\end{array}\end{array}$ & 28.50 & 88.00 & 29.80 & 14.20 & 2.05 & 41.95 & 12.00 \\
\hline $\begin{array}{l}\text { (50\% Kochia-50\% Fodder } \\
\text { beet) silage }\end{array}$ & 27.30 & 80.00 & 20.13 & 12.15 & 2.21 & 55.31 & 10.00 \\
\hline
\end{tabular}

\section{Silage quality:}

The different silages had a good physical characteristics expressed as natural color and pleasant aroma as well as a good fermentation quality (Table 2) expressed as lowering of $\mathrm{pH}$ (3.97 to 4.43), increasing lactic acid (5.95 to 6.61) and little content of butyric acid and ammonia-N. These results are in line with the finding of Shehata et al. (2001) with Kochia silage and/ or Teosinte silage

Table (2) Fermentation characteristics of different silages.

\begin{tabular}{|l|c|c|c|}
\hline \multirow{2}{*}{\multicolumn{1}{c|}{ Items }} & \multicolumn{3}{|c|}{ Groups } \\
\cline { 2 - 4 } & $\mathbf{G}_{\mathbf{1}}$ & $\mathbf{G}_{\mathbf{2}}$ & $\mathbf{G}_{\mathbf{3}}$ \\
\hline pH value & 3.97 & 4.21 & 4.43 \\
\hline Lactic acid, \% DM & 6.35 & 6.15 & 5.95 \\
\hline Acetic acid, \% DM & 2.40 & 2.29 & 2.25 \\
\hline Butyric acid, \% DM & 0.25 & 0.31 & 0.35 \\
\hline Ammonia, \% DM & 0.17 & 0.20 & 0.23 \\
\hline
\end{tabular}

\section{Blood profile:}

Data of hemato-biochemical parameters are presented in Table (3). The results indicated that most tested blood parameters were not significantly affected by the tested rations. Comparison of hematological parameters revealed small fluctuations among groups fed different rations in concentrations of Hb, RBC's, Hct, WBC's, MCHC, platelets and albumin.

On the other hand, the highest values of serum urea- $\mathrm{N}$ were recorded with $\mathrm{G}_{1}(67.87 \mathrm{mg} / \mathrm{dl})$ and lowest value was detected with $\mathrm{G}_{3}(60.60 \mathrm{mg} / \mathrm{dl})$ and the differences were significant. Meanwhile, both total protein and globulin were also higher $(7.20$ and $4.37 \mathrm{~g} / \mathrm{dl})$ with $\mathrm{G}_{2}$ than other group but without significance difference. Serum creatinine concentration showed some fluctuation among groups, ranging from 0.87 (in $\mathrm{G}_{2}$ ) to 1.03 (in $\mathrm{G}_{3}$ ) as shown in Table (3). Both AST and ALT concentrations were higher with $\mathrm{G}_{1}$ (17.67 and 159, respectively) than other groups and the differences were significant in AST concentration only. The obtained values are within the normal range reported by Jain (1986) (for hematological parameters) and Kaneko (1986) (for biochemical parameters) for healthy goats. 
Table(3): Effect of experimental treatments on some hematological and serum biochemical parameters of lactating Zaraibi goats.

\begin{tabular}{|c|c|c|c|}
\hline \multirow{2}{*}{ Items } & \multicolumn{3}{|c|}{ Groups } \\
\hline & G1 & G2 & G3 \\
\hline \multicolumn{4}{|c|}{ Hematological parameters } \\
\hline RBC's, $\times 10^{6} / \mu \mathrm{l}$ & $13.57 \pm 0.57$ & $13.73 \pm 0.98$ & $14.01 \pm 1.16$ \\
\hline Hemoglobin, g/dl & $10.37 \pm 0.64$ & $10.80 \pm 0.10$ & $11.40 \pm 0.78$ \\
\hline HCT, \% & $28.50 \pm 0.95$ & $29.27 \pm 0.32$ & $30.30 \pm 1.48$ \\
\hline $\mathrm{MCV}, \mathrm{fl}$ & $21.11 \pm 1.39$ & $21.52 \pm 1.42$ & $21.84 \pm 1.58$ \\
\hline $\mathrm{MCH}, \mathrm{pg}$ & $7.64 \pm 0.37$ & $7.94 \pm 0.51$ & $8.35 \pm 1.27$ \\
\hline $\mathrm{MCHC}, \mathrm{g} / \mathrm{dl}$ & $36.61 \pm 3.48$ & $36.91 \pm 0.35$ & $37.88 \pm 3.49$ \\
\hline T.Leucocytic count, $\times 10^{3} / \mu \mathrm{l}$ & $10.53 \pm 3.12$ & $12.40 \pm 1.00$ & $13.27 \pm 2.01$ \\
\hline Neutrophils, \% & $42.00 \pm 1.15$ & $42.67 \pm 0.88$ & $42.33 \pm 0.33$ \\
\hline Lymphocytes, \% & $54.33 \pm 0.88$ & $53.33 \pm 1.45$ & $54.67 \pm 0.88$ \\
\hline Monocytes, \% & $2.00 \pm 0.58$ & $2.67 \pm 0.33$ & $1.67 \pm 0.67$ \\
\hline Eosinophils, \% & $1.67 \pm 0.33$ & $1.33 \pm 0.33$ & $1.33 \pm 0.33$ \\
\hline Platelet count, $\times 10^{3} / \mu \mathrm{l}$ & $352 \pm 11.67$ & $373 \pm 8.82$ & $385 \pm 18.12$ \\
\hline \multicolumn{4}{|c|}{ Serum biochemical } \\
\hline Total protein, g/dl & $7.00 \pm 0.12$ & $7.20 \pm 0.15$ & $7.07 \pm 0.19$ \\
\hline Albumin, g/dl & $2.73 \pm 0.26$ & $2.83 \pm 0.13$ & $2.97 \pm 0.12$ \\
\hline Globulin, g/dl & $4.27 \pm 0.33$ & $4.37 \pm 0.28$ & $4.10 \pm 0.21$ \\
\hline Creatinine & $0.97 \pm 0.07$ & $0.87 \pm 0.07$ & $1.03 \pm 0.09$ \\
\hline Urea-N, mg/dl & $67.87 \pm 1.04^{a}$ & $66.47 \pm 1.37^{a}$ & $60.60 \pm 1.06^{b}$ \\
\hline AST, U/L & $17.67 \pm 0.67^{a}$ & $14.67 \pm 0.88^{b}$ & $15.67 \pm 0.33^{a b}$ \\
\hline $\mathrm{ALT}, \mathrm{U} / \mathrm{L}$ & $159 \pm 10.27$ & $151 \pm 18.84$ & $152 \pm 4.98$ \\
\hline ALT/AST & $8.62 \pm 0.48$ & $10.34 \pm 1.36$ & $9.69 \pm 0.34$ \\
\hline
\end{tabular}

a-b Means in the same row with different superscripts differ significantly at $\mathrm{P}<0.05$

Milk yield:

Milk yield as $\mathrm{kg} / \mathrm{h} / \mathrm{d}$ of lactating Zaraibi goats during experimental period (14 weeks) are presented in (Table 4 and Fig 1). The differences in milk yield were significant $(P<0.05)$ among the tested groups during most lactation weeks. The daily milk yield had the highest value $(0.845 \mathrm{~kg})$ with $\mathrm{G}_{1}$ (berseem silage) followed by $\mathrm{G}_{2}$ (berseem-fodder beet, $0.761 \mathrm{~kg}$ ) while the lowest value $\left(0.727 \mathrm{~kg}\right.$ ) was recorded with $\mathrm{G}_{3}$ (Kochia-fodder beet silage) and the differences were significant. Similarly, the obtained results indicated that total milk yield was significantly $(P<0.05)$ higher with $G_{1}(76.02 \mathrm{~kg})$ compared with $\mathrm{G}_{3}(65.44 \mathrm{~kg})$. Whereas, $\mathrm{G}_{2}$ recorded the medium value $(68.48 \mathrm{~kg})$ as shown in Table (4). This positive effect of berseem silage on milk yield by Zaraibi goats in mostly may be due to higher total dry matter and CP intake by this group than the other ones (Table 7). In this field, milk yield by dairy goats was gradually decreased $(1.39,1.18$ and $1.11 \mathrm{~kg} / \mathrm{h} / \mathrm{d})$ with increasing Kochia (25, 50 and $75 \%$, respectively) in the rations (Ahmed et al., 2001). 
Table (4 ): Effect of the experimental treatments on daily milk yield (biweekly) by lactating Zaraibi goats.

\begin{tabular}{|l|c|c|c|}
\hline \multirow{2}{*}{\multicolumn{1}{c|}{ Items }} & \multicolumn{3}{c|}{ Groups } \\
\cline { 2 - 4 } & G1 & G2 & G3 \\
\hline w2 & $0.788 \pm 0.03^{\mathrm{a}}$ & $0.658 \pm 0.05^{\mathrm{b}}$ & $0.610 \pm 0.01^{\mathrm{b}}$ \\
\hline w4 & $0.833 \pm 0.04$ & $0.779 \pm 0.06$ & $0.711 \pm 0.04$ \\
\hline w6 & $1.000 \pm 0.05$ & $0.946 \pm 0.07$ & $0.892 \pm 0.03$ \\
\hline w10 & $0.967 \pm 0.05$ & $0.863 \pm 0.06$ & $0.846 \pm 0.05$ \\
\hline w12 & $0.817 \pm 0.03^{\mathrm{a}}$ & $0.718 \pm 0.09^{\mathrm{ab}}$ & $0.696 \pm 0.04^{\mathrm{b}}$ \\
\hline w14 & $0.771 \pm 0.04^{\mathrm{a}}$ & $0.695 \pm 0.07^{\mathrm{ab}}$ & $0.682 \pm 0.04^{\mathrm{b}}$ \\
\hline Average milk yield, $\mathrm{kg} / \mathrm{h} / \mathrm{d}$ & $0.738 \pm 0.04^{\mathrm{a}}$ & $0.667 \pm 0.08^{\mathrm{b}}$ & $0.654 \pm 0.04^{\mathrm{b}}$ \\
\hline Total milk yield, Kg & $0.845 \pm 0.03^{\mathrm{a}}$ & $0.761 \pm 0.06 \mathrm{a}^{\mathrm{b}}$ & $0.727 \pm 0.03^{\mathrm{b}}$ \\
\hline FCM & $76.012 \pm 0.43^{\mathrm{a}}$ & $68.464 \pm 0.97^{\mathrm{ab}}$ & $65.443 \pm 0.41^{\mathrm{b}}$ \\
\hline
\end{tabular}

a-b Means in the same row with different superscripts differ significantly at $P<0.05$.

* Fat corrected milk $=($ Milk kg $\times 0.432)+($ Fat kg $\times 16.216)$.

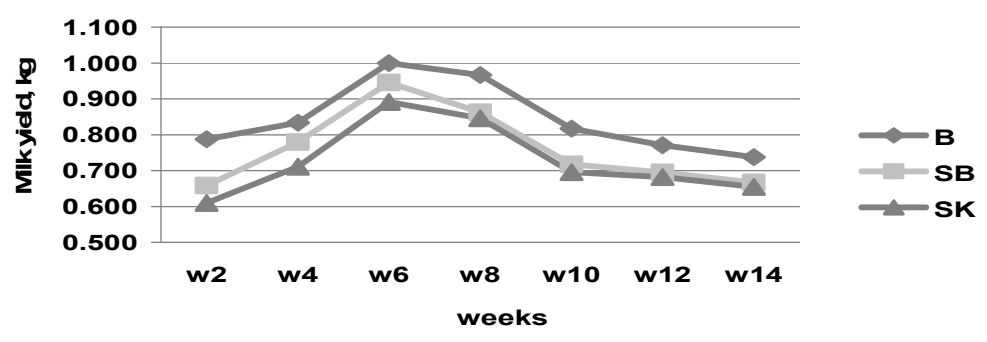

Fig (1): Average of milk yield biweekly of lactating Zaraibi goats during experimental periods.

\section{Milk composition:}

Data of milk composition presented in Table (5) show that the effect of experimental treatments on fat percentage was significant $(P<0.05)$. Milk fat percentage was significant by $(P<0.05)$ higher with group fed Kochia-fodder beet silage $(4.05 \%)$ compared with berseem only $\left(3.63 \% \mathrm{G}_{1}\right)$ or mixture with fodder beet $\left(3.52 \% \mathrm{G}_{2}\right)$ as shown in Table (5). The positive effect of Kochiafodder beet silage on milk fat \% may be due to the high content of $E E$ in Kochia-fodder beet as shown in Table (1). In this respect, Ahmed et al. (2001) observed that milk fat percentage was gradually increased $(4.16,4.21$, and $4.24 \%$ ) with the increasing Kochia silage level (25, 50 and $75 \%$, respectively) in goat rations. Similarly, total solids were higher with $\mathrm{G}_{3}$ $(12.49 \%)$ compared with other groups as shown in Table (5). But, the effect of the tested experimental rations on other milk contents (protein, lactose and ash) were not significant $(P<0.05)$. However, the average milk and fat yield wae significantly higher $(P<0.05)$ in $\mathrm{G} 1$ than the values recorded in $\mathrm{G} 2$ and G3 (Table 5). The obtained values of milk constituents for goats were within the normal range given by Ahmed (1999), Gabr et al. (1999), El-Kolany (2004), Ibrahim et al. (2013) and Ahmed et al. (2013). 
Table (5): Effect of the experimental treatments on milk composition and yield of fat and protein of lactating Zaraibi goats during experimental period.

\begin{tabular}{|c|c|c|c|}
\hline \multirow{2}{*}{ Items } & \multicolumn{3}{|c|}{ Groups } \\
\hline & G1 & G2 & G3 \\
\hline Average milk yield, kg & $0.845 \pm 0.03^{a}$ & $0.761 \pm 0.06 \mathrm{a}^{\mathrm{b}}$ & $0.727 \pm 0.03^{b}$ \\
\hline \multicolumn{4}{|c|}{ Milk composition : } \\
\hline Fat, \% & $3.63 \pm 0.05^{b}$ & $3.52 \pm 0.06^{b}$ & $4.05 \pm 0.07^{a}$ \\
\hline Protein, \% & $3.06 \pm 0.05$ & $3.00 \pm 0.04$ & $3.10 \pm 0.03$ \\
\hline Lactose, $\%$ & $4.70 \pm 0.05$ & $4.58 \pm 0.05$ & $4.64 \pm 0.05$ \\
\hline Ash, \% & $0.78 \pm 0.01$ & $0.75 \pm 0.02$ & $0.75 \pm 0.02$ \\
\hline Total solids, $\%$ & $12.17 \pm 0.16^{\mathrm{ab}}$ & $11.85 \pm 0.12^{\mathrm{b}}$ & $12.54 \pm 0.11^{a}$ \\
\hline Av. Fat yield, g/h/d & $30.67^{a}$ & $26.79^{\mathrm{b}}$ & $29.44^{\mathrm{ab}}$ \\
\hline Av. protein yield, $\mathrm{g} / \mathrm{h} / \mathrm{d}$ & $25.86^{a}$ & $22.83^{b}$ & $22.54^{\mathrm{b}}$ \\
\hline
\end{tabular}

a-b Means in the same row with different superscripts differ significantly at $P<0.05$.

\section{Some rheological properties of milk:}

The fresh whole goat's milk of different treatment groups were divided into two sections; The fresh section included the fresh whole raw goat's milk heated to $30^{\circ} \mathrm{C}$ and rennet was added. The second section included whole goat's milk of all treatments groups was heated to $72^{\circ} \mathrm{C}$ cooled to $30^{\circ} \mathrm{C}$ and $1 \%$ pure cultured of Lactococcus lactecs subsp. was added to it. From Table (6) there was no significant variation among different treatment groups in the first section as regard (RCT) while in the second section 2 (RCT) was 215 minutes for all treatment groups. This may be due to the effect of the starter on acidity development provided in the forming curd. Concerning curd tension (CT) and whey synesesis the raw goat's milk ( first section) showed higher values than when starter was added (second section). These differences may be due to increased protein content of goat's milk as affected by acidity of milk and curd (Dinov and Mineva (1963). The percentage of fat lose in the whey was approximately similar in the treatment of the two sections. These results are in agreement with those determined by Emara (1990), El-Alamy et al. (1992), Enab (1993), Mehana et al. (1998) and Ayad (2003).

Table (6 ): Effect of experimental treatments on Rennet Coagulation Time (RCT), Curd Tension (CT), whey synesesis and fat lose of whey in Zaraibi goats milk.

\begin{tabular}{|c|c|c|c|c|c|c|c|c|c|}
\hline \multirow{2}{*}{\multicolumn{2}{|c|}{ Treatment }} & \multirow{3}{*}{\begin{tabular}{|c}
$\begin{array}{c}\text { RCT min } \\
\text { sec }\end{array}$ \\
$2: 10$
\end{tabular}} & \multirow{3}{*}{\begin{tabular}{|c|} 
CT gram \\
24.59 \\
\end{tabular}} & \multicolumn{6}{|c|}{ Whey synesesis (after min) gram/15g of curd } \\
\hline & & & & \multirow{2}{*}{$\begin{array}{c}10 \\
4.22\end{array}$} & \multirow{2}{*}{$\begin{array}{c}30 \\
6.70\end{array}$} & \multirow{2}{*}{$\frac{60}{7.55}$} & \multirow{2}{*}{$\begin{array}{c}90 \\
8.09\end{array}$} & \multirow{2}{*}{$\begin{array}{c}120 \\
8.27\end{array}$} & \multirow{2}{*}{$\begin{array}{c}\begin{array}{c}\text { Fat lose of } \\
\text { whey } \%\end{array} \\
0.50\end{array}$} \\
\hline ธᄃ & G1 & & & & & & & & \\
\hline 恶 - & G2 & $2: 30$ & 24.36 & 4.34 & 6.82 & 7.61 & 8.17 & 8.39 & 0.51 \\
\hline & G3 & $2: 45$ & 24.12 & 4.45 & 6.87 & 7.76 & 8.29 & 8.51 & 0.52 \\
\hline \multirow{3}{*}{ 듬 } & G1 & 215:0 & 27.04 & 2.89 & 5.24 & 6.01 & 7.53 & 8.53 & 0.55 \\
\hline & G2 & 215:0 & 27.87 & 2.97 & 5.38 & 6.11 & 7.69 & 8.69 & 0.52 \\
\hline & G3 & 215:0 & 28.17 & 3.00 & 5.99 & 6.20 & 7.75 & 8.80 & 0.55 \\
\hline
\end{tabular}

Daily feed intake, feed conversion and economic efficiency:

The average daily feed intake of lactating Zaraibi goats is summarized in Table (7) . The total DM intake as $\mathrm{g} / \mathrm{h} / \mathrm{d}$ or $\mathrm{g} / \mathrm{kgw}^{0.75}$ tended to increase with 
$\mathrm{G}_{1}\left(1141 \mathrm{~g} / \mathrm{h} / \mathrm{d}\right.$ or $75.31 \mathrm{kgw}^{0.75}$, respectively) compared with $\mathrm{G}_{2}(1120 \mathrm{~g} / \mathrm{h} / \mathrm{d}$ or $73.01 \mathrm{kgw}^{0.75}$, respectively) and $\mathrm{G}_{3}\left(1099 \mathrm{~g} / \mathrm{h} / \mathrm{d}\right.$ or $71.78 \mathrm{~g} / \mathrm{kgw}^{0.75}$, respectively). The same trend was observed with daily intake as \% BW among the experimental treatments as shown in Table (7). These results were related to the silage quality as reported earlier in Table (2). As for the ratio of roughage to concentrate $(R / C)$, recorded $54: 46$ for $G_{2}$ and $53: 47$ for both $\mathrm{G}_{1}$ and $\mathrm{G}_{3}$. The increased roughage intake (silage) gave positive evidence that silage was of good quality.

Table (7): Feed and economic efficiency for lactating Zaraibi goats fed different experimental rations.

\begin{tabular}{|l|c|c|c|}
\hline \multirow{2}{*}{ Item } & \multicolumn{3}{c|}{ Groups } \\
\cline { 2 - 4 } & G1 & G2 & G3 \\
\hline No. of Zaraibi goats & 6 & 6 & 6 \\
\hline Average BW, kg & 37.5 & 38.1 & 38.0 \\
\hline Metabolic body size, w ${ }^{0.75}$ & 15.15 & 15.34 & 15.31 \\
\hline \multicolumn{3}{|c|}{ Daily DM intake (g/h) } \\
\hline CFM & 521 & 520 & 517 \\
\hline Silage & 610 & 600 & 582 \\
\hline Total DM intake & 1141 & 1120 & 1099 \\
\hline DM intake, \% of BW & 3.04 & 2.94 & 2.89 \\
\hline DM intake, g/kgw 0.75 & 75.31 & 73.01 & 71.78 \\
\hline $\begin{array}{l}\text { Roughage : concentrate, (R/C) } \\
\text { ratio }\end{array}$ & $53: 47$ & $54: 46$ & $53: 47$ \\
\hline CP intake & 164 & 148 & 147 \\
\hline Average milk yield, g/h/d & 845 & 761 & 727 \\
\hline \multicolumn{4}{|c|}{ Feed conversion } \\
\hline Kg DM/Kg milk & 1.35 & 1.47 & 1.51 \\
\hline Kg CP/Kg milk & 0.194 & 0.194 & 0.202 \\
\hline Economic efficiency & 1.88 & 1.76 & 1.60 \\
\hline Coast of consumed, L.E. & 2.96 & 2.66 & 2.54 \\
\hline Price of milk, L.E. & 2.22 & 2.31 & 2.20 \\
\hline Feed cost/kg milk, L.E. & 1.57 & 1.51 & 1.59 \\
\hline Efficiency, \%
\end{tabular}

The prevailing prices, per ton, at time of the study are, 2200 L.E.- CFM, 280 L.E.- S1, 225 L.E.- S2, 170 L.E.- S3 and 3.50 L.E.- milk.

Data of feed conversion efficiency of the experimental goats are summarized in (Table 7). The obtained results indicated that feed conversion calculated as dry matter intake/milk yield was better in $\mathrm{G}_{1}(1.35)$ than $\mathrm{G}_{2}$ (1.47) and lastly, $\mathrm{G}_{3}$ (1.51). Also, the feed conversion calculated as $\mathrm{CP}$ intake/milk yield was increased in $\mathrm{G}_{3}$ (Kochia-fodder beet) compared with berseem $\left(G_{1}\right)$ and their mixture with fodder beet. In this respect, Ahmed et al. (2001) observed that feed conversion as DM and DCP by dairy goats was higher with substation of teosinte by Kochia in silage rations. Generally, these results were related to the milk yield as reported earlier.

\section{Economic efficiency:}

As for economic efficiency in Table (7), the results indicated that feed cost $/ \mathrm{kg}$ milk tended to increase with $\mathrm{G}_{2}$ (berseem-fodder beet), compared 
with $\mathrm{G}_{1}$ (berseem silage) and $\mathrm{G}_{3}$ (Kochia-fodder beet). Thus, the lowest value of economic efficiency was detected with $\mathrm{G}_{3}(1.59)$.

In this respect, Ahmed et al. (2001) found that the economic efficiency was greatly improved with substitution of Teosinte by Kochia silage in small ruminant rations.

\section{CONCLUSION}

From the foregoing results, it is recommended for using kochia-fodder beet silage in goat rations beside berseem-fodder beet silage, since the latter is becoming scarce and expensive. Kochia-fodder beet silage can be successfully fed to lactating goats without any adverse effect on performance and animal health in general, and it can economically substitute both of berseem and berseem-fodder beet silages. Further studies are needed to evaluate the kochia fodder in different forms (hay-fresh-silage) at different levels as will as with other sources of energy feed additives with different farm animals.

\section{REFERENCES}

A.O.A.C. (1984).Association of Official Analytical Chemists Methods of Analysis $14^{\text {th }}$ Ed., Washington, DC., USA.

A.O.A.C. (1995). Official Methods of Analysis $16^{\text {th }}$ Ed., Association Analytical Chemists, Washington, DC., USA.

Ahmed M.E., E.I. Shehata, M.E. El-Kholany, G.I. El-Emam, E.I. Khalifa and H. Bahery (2013). Productive performance of Zaraibi goats fed berseem and/or triticale silage. The $4^{\text {th }}$ Scientific Conference of Animal Production Research Institute, P: 184.

Ahmed M. E., A.M. Abdelhamid, F.F. Abou Ammou, E.S. Soliman, N.M. ElKholy and E.I. Shehata (2001). Response of milk production of Zaraibi goats to feeding silage containing different levels of teosinte and Kochia. Egyptian J. Nutrition and Feeds, P: 4.

Ahmed M.E. (1999). Improving feed conversion efficiency during reproductive-stress. Ph.D. Thesis, Fac. Agric. Mansoura Univ. Egypt.

Ayad K. M. K. (2003). Studies on some dairy products. Ph.D. Thesis, Fac. of Agric., Mansoura Univ. Egypt.

Barnett, A.J.G. and G. Abd El-Tawab. (1957). Determination of lactose in milk and cheese. J. Sci. Food Agric., (8): 437.

Chandrosekhara, M.R., Bhajawan R.K., Swaminan M. and Subrahmanyan V. (1975). The use of mammalian milk food processed with food in feeding of infants. Indian J. child health, P: 701.

Davies, D.T. and White, J.C.D. (1958). The relation between the chemical composition of milk and stability of caseinate complex. 11. Coagulation by ethanol. J. Dairy Res., P: 25.

Dimov N. and Mineva P. (1963). Effect of some factors on the synesesis of fresh curd and losses of solids in the whey in the processing of cow's ewe's and buffaloes milk . Dairy Sci. Abst,. 
Donosa R. E. (2010). The nutritive value of fodder beet in some dairy cow farms from Verseni village (lasi County). Lucrari Stiintifice, Universitatea de Stiinte Agricole Si Medicina Veterinara "Ion Ionescu de la Brad" lasi, Seria Agronomie, 53(1): 207.

El-Alamy H.A., M.H. El-Senaity and A.M. Kholif (1992). Manufacture of white soft cheese from goat milk supplemented with skim milk powder. J. Agric. Sci. Mansoura Univ. 17(12): 3875.

El-Emam G.I., Y.H. Hafez, H. Bahery, E.I. Khalifa, E.I. Shehata and M.E. Ahmed (2014). Growth performance and some rumen and blood parameters of growing Rahmani lambs fed diets containing Triticale and berseem silages and their mixture. Egyptian J. Sheep and Goat Sci., 9 (1), April: 67.

El-kholany M.M. (1998). Substitution of sweet sorghum or clover by reed plants in rations of locating goats. M.Sc. Thesis, Fac. of Agric., Mansoura Univ. Egypt.

El-Kholany, M.M (2004). Evaluation of some new green fodder for farm animals. Ph.D. Thesis Fac. of Agric, Mansoura Univ. Egypt.

Emara H.M.M. (1990). Studies on soft cheese. Ph.D. Thesis, Fac. of Agric., Mansoura Univ. Egypt.

Enab A.K.M. (1993). Studies on the use of goat's milk in cheese production. M.Sc. Thesis. Thesis, Fac. of Agric., Cairo Univ. Egypt.

Gabr A.A., A.Z. Mehrez, E.S.M. Soliman and M.El-Kholany (1999). Response of lactating goats to diets containing reed grass ( Aroundo domax L.) versus sorghum plants, Egyptian J. Nutrition and feeds, 2 ( special Issue), 297.

Haggag M.El-H., E. S. Soliman and M.E. Ahmed (2002) Triticale forage as a feed for sheep. Proc., $1^{\text {st }}$ Ann. Sc. Conf. Anim. And fish prod, Mansoura, Sep., P: 77.

Hanafy M. A., Fahmy A.A., Farghaly M.S. and El-Shereef A.A. (2013). Effect of different treatments on digestibility coefficients and nutritive values of Kochia plant by sheep. Egyptian Journal of Nutrition and Feeds. 16(2 (Special Issue)): 257.

Hanafy, M.A., Fahmy A.A., Farghaly M.S. and El-Sheref A. A. (2011). Using alternative sources of roughages or concentrates for Barki ewes feeding Egyptian Journal of Nutrition and Feeds. 14(2): 217

Ibrahim, F.A. K.M.K. Ayad, M.E.Ahmed and M.E. El-Kholany (2013). Effect of using chufa tubers (Cyprus esculantus L.) in Zaraibi goats diets on the resultant milk and labinah. Egyptian j. of sheep and goat sciences, vol. 8 (1): 201.

Ibrahim, F.A., Soliman, E.S, A. A. Abd El-Hamid and M. E. Ahmed. (2012). Growth performance and feed utilization efficiency of Rahmani lambs fed some legume And/Or grass silages. Egyptian j. of sheep and goats sciences, vol. 7 (2): 1.

lacob, T., Vientu, V. Samull, C. (1997). Plante furajere- techologil de cultivare, Ed. Junimea, lasi.

Jain N. C.(1986). Veterinary hematology $4^{\text {th }}$ Ed., Lea. and Febiger. Philadelphia. 
Keneko. I.H. (1986). Chemical Biochemistry of Animals. $4^{\text {th }}$ ED. Academic Press, Inc USA.

Laurernce, A. J. (1959). Synesesis of rennet curd. J. Dairy Technol., P: 14.

Ling E.R. (1963). Test book of dairy chemistry, vol. 2. (Bacterial). $3^{\text {rd }}$ Ed. Champan and T D. London.

Marius C., Sollberger, H. Butikofer, U. and Sieber, R. (2004). Impact of a basal diet of hay and fodder beet supplemented with rapeseed, linseed and sunflowerseed on the fatty acids composition of milk fat. International Dairy Journal (14): 549.

Mehana M.Y., El-Shazly, A.A., Nasr M.M. and Ayad K.M. (1998). Studies on Domiati cheese, 1- yield, gross chemical composition and physical properties of curd of goat's milk as affected by feeding rations. J. Agric. Sci. Mansoura univ., 23(11): 49.

NRC (1981).Nutrient Requirements of Domestic Animals. Nutrient Requirements Of Goats. National Research Council, Washington, D.C. USA of Official Analytical Chemists, Washington, D.C., USA.

SAS Institute (2003). SAS/STATR User's Guide: statistics. Ver. 9.1, SAS Institute Inc., Cary, NC, USA.

Shehata E.I, M.E. Ahmed, A.M. Abdelhamid, Faten F. Abou Ammou and M. El-H. Haggag (2001) Comparative nutritive values of silage ration containing different level of teosinte and Kochia . Egyptian J. Nutrition and feeds, (4):129.

Sherrod L. B. (1973). Nutritive value of Kochia Scoparia ш . Digestibility of Kochia hay compared with alfa alfa hay . J. of Dairy Sci., P: 56.

Tag El-Din A. E., A. A. Nour, M. A. Ahmed and S. M. Zahran (1991). Utilization of Kochia indica in complete diets for ruminants. Alex. J. Agric. Res., P: 36.

Zahran, M. A. (1986). Forage potentialities of Kochia indica and K. Scoporia in Arid lands with particular reference to Saudi Arabia Gulf Journal of Sci. Res., P: 4. 


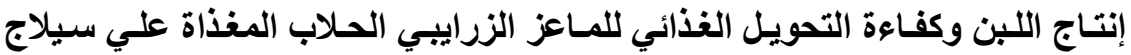

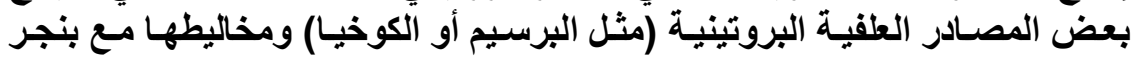

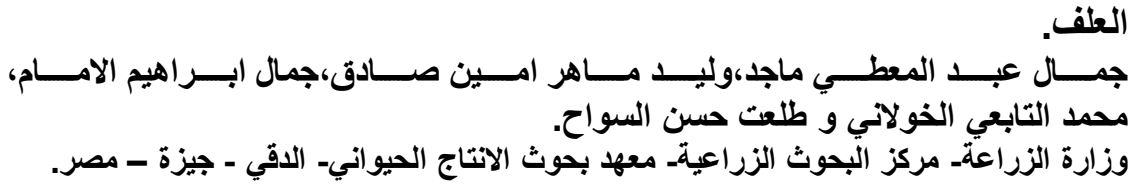

أجري هذا البحث بهدف دراسة تأثير إحلال سبلاج الكوخيا محل سبلاج البرسيم المخلوط مع بنجر

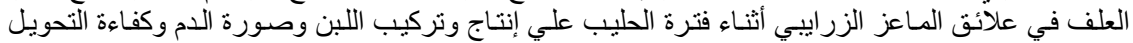

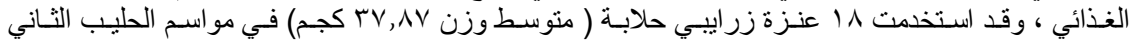

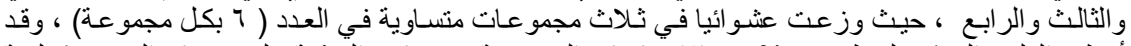

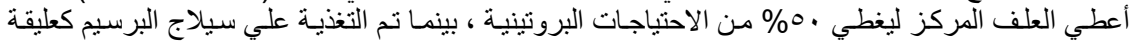

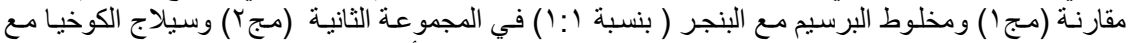

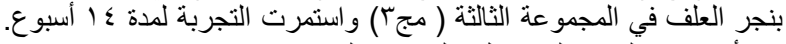
وقد أوضحت أنتائج المتحصل عليها كما يلى الئى

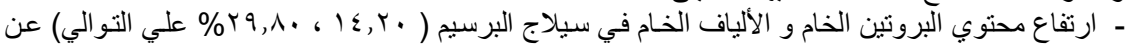

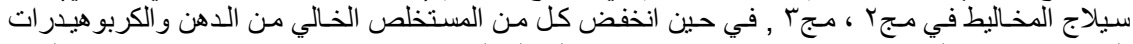

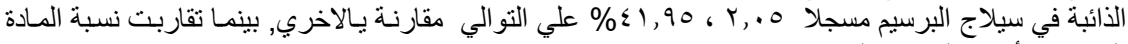

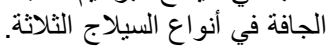
- فيما يتعلق بقياسات الدم: فقد أظهرت معظم القياسات تأثرا غير ملحوظ عند تغذية المـاعز الزرايبي الحلاب علي علائق السيلاج المختبرة.

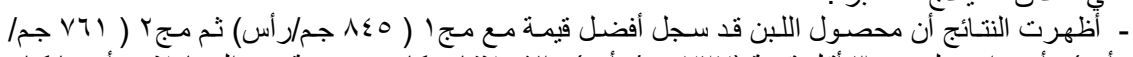

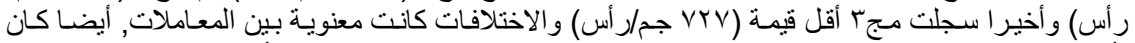

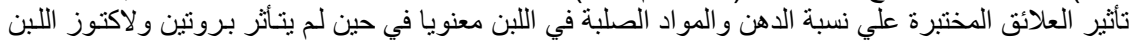
وكذلك صورة اللبن بالعلاثق المختبرة.

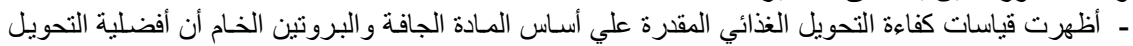

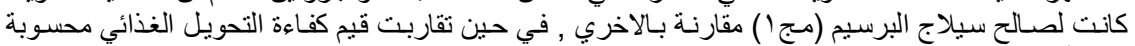

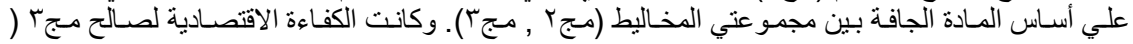

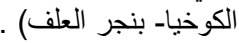

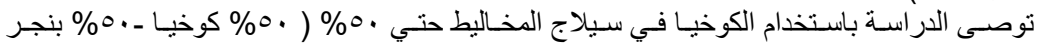

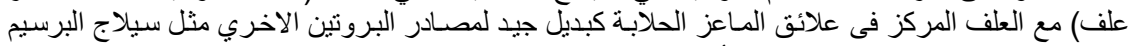

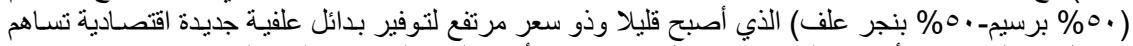

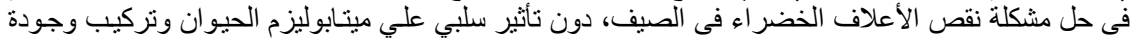

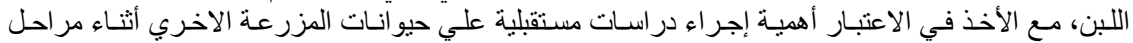

